\title{
Revisiting Sándor Ferenczi in light of current educational practices
}

\section{Revisitar Sándor Ferenczi à luz de práticas educativas}

\section{Revisitando a Sándor Ferenczi a la luz de prácticas educativas}

\section{Ana I nés Heras Monner Sans*}

Centro de Estudio de las Desigualdades, Sujetos e Instituciones, CEDESI-UNSAMCONICET, San Martín, Argentina

\begin{abstract}
I analyze the pedagogical orientation of a team of educators who run an educational center (CEIA hereafter) in the city of Buenos Aires, Argentina, that provides elementary public schooling to children, youth and adults living in extremely challenging conditions (i.e., have difficulties accessing basic health-care, work, education and housing). I focus on establishing connections between their work and that of Sandor Ferenczi's original notion of mutual analysis. For this purpose, I first present some aspects of the historical context in which Ferenczi lived and developed his theory, showing that mutuality was an orientation that permeated his life and work. I thus analyze two pedagogical devices identified at the CEIA in light of the framework of mutuality, following which I present a discussion that highlights the relationship between the educators' approach, which I identify as clinical-educational, and Ferenczi's notion of mutuality. I conclude that Ferenczi's ideas - novel at the time- are still current, if not novel, provided we ask what can be learned from them. My methodology combines a historical perspective with ethnography and sociolinguistics in two respects: analyzing the educators' pedagogical framework, and examining historical data in that light.
\end{abstract}

Keywords: Ferenczi, education, collaborative ethnography.

\section{RESUMO}

Analiso a orientação pedagógica de uma equipe de educadores que dirigem um centro educativo na cidade de Buenos Aires (CEIA), na Argentina, que fornece a instrução pública elementar a crianças, jovens e adultos que vivem em condições extremamente desafiantes (isto é, têm dificuldades em acessar o serviço de saúde básico, o trabalho, a educação e o alojamento). Concentro-me em estabelecer conexões entre o seu trabalho e aquela da noção original de Sandor Ferenczi da análise mútua. Com esta finalidade, primeiro apresento alguns aspectos do contexto histórico no qual Ferenczi viveu e desenvolveu a sua teoria, mostrando que a mutualidade foi uma orientação que permeou a sua vida e trabalho. Assim analiso dois dispositivos pedagógicos identificados no CEIA na luz da armação da mutualidade, depois da qual apresento uma discussão que destaca a relação entre a aproximação dos educadores, que identifico como a noção de, e Ferenczi clínico e educativo da mutualidade. Concluo que as ideias de 
Ferenczi - a novela no momento - ainda é atual, se não novo, contanto que perguntemos o que pode aprender-se de eles. A minha metodologia combina uma perspectiva histórica com etnografia e sociolinguística em dois respeitos: análise da armação pedagógica dos educadores e exame de dados históricos naquela luz.

Palavras-chave: Ferenczi, educação, etnografia colaborativa.

\begin{abstract}
RESUMEN
Analizo en este trabajo la orientación pedagógica de un equipo de educadores que llevan adelante un proyecto en la ciudad de Buenos Aires (CEIA), Argentina, dirigido a niños/as, jóvenes y adultos que viven en situaciones de extrema vulnerabilidad con dificultades de acceso a cuidado de la salud, al trabajo, a una educación y vivienda dignas. Establezco relaciones entre el trabajo de estos educadores y la concepción de mutualidad elaborada por Ferenczi a partir de su noción específica de análisis mutuo. Para ello primero presento una revisión del contexto histórico en que Ferenczi desarrolla su trabajo y puntualizo aspectos distintivos de su práctica profesional. Identifico así que su noción de mutualidad surge de su enfoque profesional y de su posición vital. Luego analizo dos dispositivos educativos en la escuela de Buenos Aires a la luz de esta concepción de mutualidad. Finalizo en el último apartado señalando las relaciones entre dicha concepción y el trabajo de los educadores, para concluir que el enfoque de Ferenczi continúa aún vigente. He trabajado con una metodología que combina el análisis histórico con una documentación y análisis etnográfico para las interpretaciones producidas.
\end{abstract}

Palabras clave: Ferenczi, educación, etnografía colaborativa.

\title{
Introduction
}

In this article I analyze the pedagogical orientation of a team of educators who run an educational center (CEIA for its acronym hereafter) in the city of Buenos Aires, Argentina that provides elementary public schooling to children, youth and adults living in extremely challenging conditions (i.e., have difficulties accessing basic health-care, work, education and housing). At the time I wrote this piece I had been collaborating with them for three years as a researcher, documenting and analyzing their educational approach. In this article I focus on establishing connections between their work and that of Sandor Ferenczi's original notion of mutual analysis. For this purpose, I first present some aspects of the historical context in which Ferenczi lived and developed his theory, showing that mutuality was an orientation that permeated his life and work, and that emerged from his particular life circumstances. In the section that follows I analyze two pedagogical devices identified at the CEIA in light of the framework of mutuality. In the third and concluding section I present a discussion that highlights the relationship between the educators' approach, which I identify as clinical-educational, and Ferenczi's notion of mutuality. I conclude that Ferenczi's ideas novel at the time- are still current, if not novel, provided we ask 
what can be learned from them. My methodology combines a historical perspective with ethnography and sociolinguistics in two respects: analyzing the educators' pedagogical framework, and examining historical data in that light.

\section{Section One}

\section{Ferenczi and his time}

Sándor Ferenczi (1873-1933) was a Hungarian psychoanalyst who lived in a time in which the European world was changing rapidly (Tilly, 2010; Hobsbawm, 1995). All across Europe there were tensions between aristocracy and the emerging bourgeois class, and between the bourgeois and the working class and peasants. There were also conflicts surrounding religion (e.g. Jews were not recognized as full citizens by several states); tensions over civil rights (e.g., whether females could vote), and complexities and difficulties associated with the ethnic, linguistic and cultural affiliations of several different groups (e.g., those who reclaimed their rights within the territories in which they lived, or that fought for an independent nation). Wallerstein (2011) has pointed out that the capitalistic system that was forming during those times proclaimed equality as the goal, even in the face of evident disparity. Thus, it was during those years that questions about inequality acquired public status and began to permeate society. Wallerstein (2011) has posited that one of the responses to these issues was the formation of nation-states and the status of citizen, in as much as these mechanisms maintained some control over the tensions that inequality created. It was also during these times that psychoanalysis was created, and some of its work was oriented towards analyzing society, as well as interpreting the individual's response to society's demands (Roudinesco, 2015).

In Central Europe, social, political and economic conflict was part of the scene: borders changed, new nations emerged, several groups developed distinct collective organizations (e.g., unions, political parties and interest groups) and scientific developments demanded new kinds of organizations within academic settings (Evans, 2006). The cover term Mitteleuropa (Central Europe) was also being crafted at that time. Even if Mitteleuropa defined a space that shared commercial, intellectual and political interests, bounding what later became Austria, Hungary and Germany, the Hungarian Kingdom was distinctive in that scene, in that it hosted several different peoples, who spoke their own languages, and identified with specific cultures (e.g., Slovene, Rumanian, Croatian, Serbian, German and Hungarian). They also professed different religions. After a series of 
tensions during 1848-1867, Hungary and Austria signed a Compromise whereby they were recognized as co-equals within the Austro-Hungarian Empire (Banki, 2007). As a consequence of WWI, however, this Empire was dismantled. Starting in 1918, Hungary faced a continuum of drastic changes, that is, the Károlyi Regime in 1918, the White Terror in 1919, the Horthy Regime from 1920 to 1944 (Haynal, 2009). During the first decade of the XX century Hungarians pursued the idea that Budapest could become a gravitational intellectual center within Mitteleuropa (Evans, 2006), and in particular, this had an effect on psychoanalysis (Roudinesco, 2015). Haynal has highlighted that Hungarians developed a sense of uniqueness about their history as a nation-state, due, in part, to their linguistic specific characteristics.

Around that time, Mittleuropa saw the emergence of several new academic disciplines, particularly in Germany and Austria. For example, the beginnings of psychology are dated around 1879, and other disciplines, such as philosophy, re-defined their goals and fields of expertise (Peres, 2015) in light of the development of related areas, including experimental psychology and sociology. Psychoanalysis was created anew, and its beginnings as a field can be interpreted in the context of its relationship with psychology, philosophy, medical science, and other body therapies. Katz (1977) pointed out that psychoanalysis "conquered a great part of what was within the field of medical pathological themes in favor of the field of psychology" (my translation, original in Portuguese).

Apart from the debates with other disciplines, psychoanalysts also faced internal deliberations and -at certain points- arguments. They discussed techniques, methodologies, constructs, and theoretical frames. In as much as it was a new field, there was a need to establish certain conceptual frames to be acknowledged as common ground. The focus was the treatment of neurosis, initially. In the years following 1910, however, the scope extended.

The International Association had been already created, Annual or $\mathrm{Bi}$ Annual meetings were taking place, and a few years later, WWI took place, and it was a tremendous shock for all involved.

Freud and other psychoanalysts reflected critically on their times and on the consequences that the institutions and social regimes inflicted on individuals. Thus, already at this early stage, the discipline is conceived both as therapy for individual patients and as a clinical orientation towards understanding the individual and society in their relationship (Castoriadis, 1992).

One of the matters reflected upon, and also discussed internally, was the issue of power relations and hierarchal relationships within organizations. Such issues, too, were reflected within the psychoanalytic movement. For example, who could join the discipline and practice it, in which specific ways, and who and why could 
become a figure of authority by way of presiding over the Association, or becoming Chief Editor of their Journal, as it is documented extensively in Freud's correspondence and writing (e.g. Múltiple Interés del Psicoanálisis published in 1913), and discussed by several authors who have analyzed the institutionalization of psychoanalysis (Montejo-Alonso \& Chamorro-Romero, 2011).

Members from different countries, such as Austria, Hungary and Germany, joined the psychoanalytic movement between 1900 and 1910. This core group of psychoanalysts used German as their way of communicating. However, some of them spoke other languages as their mother tongue, or were bilingual or multilingual by birth. Soon after, the movement extended beyond Mitteleuropa, reaching also London and New York, and later, Paris, Madrid, Sao Paulo and Rio de Janeiro (Katz, 1977), and Buenos Aires (Dagfal, 2009). Psychoanalytic literature was translated, such as Freud's original work, or produced in different languages (e.g., English, Spanish, Portuguese, French, Italian).

\section{Ferenczi's work and his notion of mutual analysis / mutuality}

Amongst the early psychoanalysts, writing both in German and Hungarian, was Sándor Ferenczi, a Hungarian medical doctor who met Freud in 1908 when he was 35 years old. At that time he had already explored different treatments for neurological diseases, experimented with hypnosis, and researched on several different areas. His interests were broad (Gutiérrez-Peláez, 2013; Haynal, 2001; Roudinesco, 2015), as can be inferred from reading a complete list of his published work in Hungarian and German, including the arts (he wrote poetry and was keen in understanding the debates around Art Nouveau), politics (he followed the debates about women's rights) and socio-cultural matters (for example sexual mores, the emergence of new bodies of knowledge or tourism as a social phenomenon).

Even though he was familiar with Freud's work while he was being trained as a medical doctor, he had initially dismissed it, and yet he had a chance to meet Freud in 1908 and started to pursue his training as a psychoanalyst with him. He very quickly became more than a disciple to Freud, who addressed him as "my son". As a result, as early as 1910, Ferenczi was working with Freud in establishing the Internationale Psychoanalytische Vereinigung and was the keynote speaker at the First International Conference in Nüremberg. In that speech, for example, he reflected extensively on how an organization of peers can count on each member for its development, provided that all of them are considered equal and are granted the same status. Additionally, he supported the idea that in any such organization, leadership could be taken up by those who would labor the most, and be respected the most by their contributions and hard 
work, and not by an authority based on "an absurd tyrannical attitude" (Ferenczi, 2009, originally written and presented in 1910).

According to Roudinesco (2015), by 1918, Ferenczi supported the idea of Budapest becoming a center for a type of psychoanalysis characteristic of Mitteleuropa and distinguishable, as such, from other orientations, given the cultural, artistic and intellectual atmosphere of that city. In the end psychoanalysis instead gravitated towards Berlin and Vienna, due to a series of political changes taking place during those years and until WWII in Hungary. Nonetheless, Haynal (2002), Erös (2015) and Mészáros (2009) documented that Hungary did develop a specific orientation that was later recognized as idiosyncratic, and much of it is owed to Ferenczi's approach.

What was different, then, about Sándor Ferenczi? Where did he come from? During those final decades of the XIX and beginnings of the XX century it was usual that families moved around, and established themselves in different cities or nations. Sándor Ferenczi was born in such a migrating family. Around 1853 his mother and father settled in Miskolc, a city in the north of Hungary known to be a place where families coming from the East and the North could enter Hungary. Rosa Eibenschüts, the mother, and Baruch Fränkel, the father, (later Ferenczi) married and established a home in Miskolc, where twelve sons and daughters were born, of which Sándor was the eighth (fifth of the males).

Due to its origins, Ferenczi's was a family where several languages were spoken (Yiddish, Polish, German and Hungarian), where political ideas were discussed daily, and where political participation for a cause was a part of everyday activities (Haynal, 2002). These experiences seem to have formed Sándor's perspectives at an early age and remained core to his professional ideas and his political ideology over time.

I have emphasized elsewhere that he remained truthful to his ideas of justice, fairness, openness and search for truth throughout his life; he was conscious too that this stance made him also suffer to the point of becoming terminally ill (Heras, 2015a). Coherent with these core principles, he maintained an open interrogation of his clinical work, put it up for debate, and sought to establish relationships between psychoanalysis as a discipline and society's problems of the time. These were likely common actions for psychoanalysts at that point, but he certainly possessed some distinctive traits. For example, while promoting the idea that psychoanalysis be taken up as an analytical frame for society, he opened the Budapest meetings to people who were not doctors or professional therapists, but instead artists, educators or people who related to culture or other professions (Ëros, 2010). Additionally Flaskay (2012) has pointed out that several attendees would come along with their families, thus creating an open atmosphere for discussing issues relating to society. 
Mészáros (1998) describes as Ferenczi's "main attitude, his interdisciplinary open-mindness". Not only did he try to explicitly establish a relationship between psychoanalysis and the problems of the time, but he also seems to have been open to integrating difference of thought. For example, he was supportive of people who were coming up with new and distinct ideas, as was the case with Mélanie Klein, whom he guided and encouraged to pursue her work on children; he also included in his group people like Géza Roheim and Deveraux, who explored the relationships between psychoanalysis, ethnography and cultural anthropology (Haynal, 2009).

I infer that this attitude was probably related to the way in which he grew up: his household, as I pointed out, was multilingual, his family was a migratory one, his father participated in politics, and his father's library and printing shop was a meeting place for people to discuss current issues. I also suggest that Ferenczi's capacity to take seriously people from different backgrounds, cultures, languages and interests was modeled after his friend Miksa Schachter, an older and prestigious Hungarian physician, who encouraged him, early in his career, to think and write broadly on various different issues (Ferenczi, 1993), and who challenged his thinking process while making explicit that they thought differently about some issues.

It is documented also that Ferenczi participated in the meetings of the Galileo Circle by 1909, that he founded the Hungarian Psychoanalytical Association in 1913, and that he was appointed Professor to teach the first University Psychoanalytic course, world wide, in Budapest (Ëros, 2010; Gutiérrez-Peláez, 2013). Both in the Galileo Circle and in the Budapest Psychoanalytical Association the issues discussed can be thought of as radical for that time, such as the rights of homosexuals, international communism, anti-militaristic positions, and the changes associated with the fall of the AustroHungarian Empire. Therefore an overall ideological position can be inferred from his practice as a clinical therapist, analyst of society, intellectual, teacher, and researcher: an approach towards listening, working with others, providing a safe environment for generating knowledge without silencing contrasting positions, an attitude of curiosity to follow new paths as they were identified with others, and a stance of support towards exploring questions or problems posed by others. In all these respects his position seems to be distinct from that taken up by many of his contemporary colleagues, and distinctive in that it was both a professional mode of being a psychoanalyst and a political stance towards others and to the society in which he lived. I am calling these capacities a clinical-educational approach, in as much as it is based on a critical examination of issues (clinical) and also seeks to be educational (for all involved, including himself). 
To support this claim, I will add that Moreau-Ricaud (2004) and Haynal (2009) have stressed the fact that he was also an excellent teacher, one that would develop confidence, and support his disciples in their curiosity to explore fields unknown at the time. I interpret that this educational quality is related to Ferenczi's capacity to empathize with others, which has been widely documented in the literature.

However interesting his approach may be today, it is well documented that during his life he was objected to the point of being excluded and ignored in his last years. Even Freud and Jones tried to stop Ferenczi from publicizing some of his ideas, technical advancements and research (Likierman, 1993). Nonetheless, Ferenczi was well known in his time for studying different cures, such as active analysis, mutual analysis, and a therapy based on the effects of analyzing counter-transference (Ferenczi, 1997; Fortune, 1993, 1996), and for engaging in clinical work with particularly difficult patients (Haynal, 2002, 2009). It has been acknowledged that his advancements provided solid ground for what later came to be the current field of relational therapy (Fortune, 2008; Tubert-Oklander, 2013).

Ferenczi's drive to provide a comfortable environment for patients prompted deeper explorations of his capacity to take seriously the contributions of the "other". In doing so, he was open as to whom he considered "an-other" with whom he could discuss his ideas, so that he extended that range from his peers and colleagues, to his patients, and even to his wife, with whom, according to his correspondence with Freud, he often times discussed his clinical preliminary results (Freud-Ferenczi Correspondence, 1908-1919). For this reason, he also sought a relationship with others who wanted to innovate, who supported divergent and diverse ways of thinking, or who were willing to try out different healing therapies such as Georg Groddeck (Fortune, 2015). As illustration of such diverse interests and an attitude of respect towards diverse identities we can cite his work with and writing on prostitutes, homo- and trans-sexuality, and abused children; his extensive research on new technical therapeutic ways, mostly documented in his later writings (e.g., Clinical Diary); his commitment to unmasking hypocrisy and understanding how adults cover up their manipulation of children (his Confusion of Tongues for example); his writings on education and on how psychoanalysis could also inform other areas such as justice or the practice of law. These capacities and interests are core to his developing a perspective based on mutuality, grounded in a deep educational interest, and juxtaposed within his clinical approach. As I have been building my argument to this point, it becomes clear that I am proposing to understand the notion of clinical to refer not only to 
therapy or healing procedures with individuals but also to an attitude directed at critically interpreting society and our contributions to it.

From my perspective, three themes stand out across his life that contributed to the shaping of his notion of mutuality. These are: his interest in siding with those who suffer and who may be not cared for by others, restoring, in his work with them, a sense of possibility to overcome their suffering; his profound sense of relationships, based on care and mutual respect, that in turn, could support a kind of nonprejudicial exchange based on honesty; and his interest in a transformative capacity that humans can resort to and build upon, which I will call an educational interest.

These, I contend, are the basic notions on which is based the clinicaleducational approach developed by educators at the Educational Center in Buenos Aires. I will describe and analyze it in the sections that follow.

\section{Section Two}

\section{Pedagogical orientation of the CEI A team of educators}

Taking what I have presented in the prior section as an interpretive background, I analyze here the pedagogical orientation of a team of educators who collectively run a public elementary school in the city of Buenos Aires, Argentina (Centro Educativo Isauro Arancibia or CEIA). These educators work with children, youth and adults living in extremely challenging conditions. They started their school project in 1998 within the public educational system.

I have been collaborating with them for three years as a researcher documenting their educational approach. In other publications I have analyzed their collective approach to managing the school, the specific ways in which they interact to accomplish their task, their ideological and educational orientation, and their capacity to interpret and propose changes to public policy (Heras, 2014a, 2014b, 2015b). In this manuscript I analyze their clinical-educational perspective, which can be linked to Sandor Ferenczi's original clinical and educational notions, and also to his orientation to mutuality, as described above. Even though I have described the link between Ferenczi's framework and the framework of parity and mutuality encountered in organizations that orient themselves to autonomous decision making processes elsewhere (Heras et al., 2013), in this article I want to emphasize what can be specifically found in CEIA's approach as a school, when we think about it from a clinicaleducational perspective. A brief word about methodology follows. 


\section{Methodology}

I have been conducting collaborative research with this collective of educators for three consecutive school years (2013-2015). Prior to that, I met and worked with them as a network of community and academic organizations that collaborate to support homeless families in the City of Buenos Aires (called Espacio Mugica). After working together at this network for a year, they approached me to think through some specific educational issues at their school, and so we agreed that I would serve as a consultant for them as well as perform other tasks we would identify as we went on. I would document and analyze their work as part of my research activities and line of inquiry.

Currently I spend 4 to 8 hours a week with them from March to December (the Argentinean academic calendar year), documenting their weekly assemblies and other spaces in which they choose to work with me. Over time they have also asked me to analyze specific situations with them, to collaborate in grant proposal writing, to participate in educational activities they were holding or planning to hold, and to act as a supporter of anything they considered key, such as, for example, their struggle to keep the school building which was threatened to be demolished by the city government.

I participate as an observer, as an educator, as a co-participant, as a colleague, as a friend, and as a professional researcher, depending on what is agreed upon, which is typical for ethnographically informed research as I have been conducting it over the past 20 years. I term this type of approach collective knowledge generation (Heras, 2014c, 2015c), based on my prior work as a school teacher, member of a workers' cooperative and research school partner (Heras, 1993, 1999).

My analytical framework for what is present in this section builds on the notion of device. I follow this analytic perspective for two reasons. First, it is a term and concept used by the educators at the school to indicate that a specific place and time is created with a purpose in which several different lines converge. Examples of the use of the term are abundant in my field notes.

I also follow an understanding of device based on work by Deleuze, Guattari and Foucault whereby a device is an identifiable situation that can be analyzed to understand an institution because it is there that practices and their attributed meanings can be traced; see Heras (2011) for a detailed discussion of this concept and its uses in analytical ethnographically based research. 


\section{Presentation of data: CEI A's devices}

In what follows I will present and analyze two devices: the weekly assemblies and the female students' meeting group.

1. Thinking collectively: the weekly assemblies. This public school has developed a school-based collective management device for making all decisions concerning their work, called the weekly assembly. This way of managing the school is characteristic of educational settings in Argentina that are run by their workers (teachers, educators, other collaborators), that is, it is characteristic of self-managed educational settings (escuelas auto-gestionadas). There are only a few in our country that are recognized as public (state owned) self-managed schools, and they are mostly middle and high schools. Therefore, CEIA is an exception in that it is an elementary school to which also a preschool and arts and crafts workshops were added over time.

The CEIA's team is composed by teachers, psychologists, social workers, artists, assistants, and other specialists (e.g., literacy adult education, early childhood education), and meets for three to four hours every Friday. They organize the topics for discussion in an open agenda, using the blackboard to write down themes.

I have been participating in these assemblies since 2013, and I have determined that these meetings serve two main purposes, according to participants' views: planning and debating. Therefore, usually, assemblies are divided into two main blocks of time. When they plan, educators inform one another about different events and activities that will take place during the week after.

When they share issues for debate, they engage in analysis, clarification, discussion, and usually make decisions. Every week I document the assembly in writing, and sometimes I use an audiorecorder and take pictures as well. Over the weekend I send them my notes. Examining this corpus of notes, which are both field-notes and assembly records, has allowed me to identify specific interactional patterns during their exchanges.

One such pattern is what I termed the clinical approach during 2014. As we discussed my use of the term clinical with the educators, and the patterns I was finding constant, we were able to identify a sequence, as follows:

The person presenting the issue takes up the turn and explains what needs to be discussed or presents the facts of (something that happened) as they saw it;

Other educators may add information, may challenge the view presented (e.g., because they saw the same issue differently), or may ask questions to the one who is presenting; 
A time for debate is then opened up;

While the issue is being debated, often times a conceptual perspective that had already been agreed upon by the educators is brought to the discussion (e.g., the three level approach that has been defined as "everything that happens to an individual student needs to be processed with them, with the group / classroom where he or she is at, with others that may be affected or related to the issue under discussion");

Other perspectives are shared, usually from different professional points of view (e.g., psychological and psychoanalytical; social work; pedagogical; medical; etc.) and evidence is discussed following these different perspectives, making visible that what counts as evidence may vary according to the perspective at hand;

A decision is reached, or else, a decision to leave the issue on "stand-by" is taken (if the educators think they can not reach an agreement or that more informational elements are needed, the decision is post-poned).

This interactional pattern rests on implicit understandings that were built over time, which I have reconstructed through my ongoing observation and by conducting interviews with several of the participants. These implicit understandings act as a dynamic framework, as characterized by the educators, and my reconstruction defines it as follows: the assembly is the maximum decision making authority, and thus it is a collective authority that rests on the capacity of building trust and constructing knowledge across different perspectives. Conflict may be part of this process of trust-building and knowledge-construction, and, according to the participants, the place where conflict should be addressed is the weekly assembly. All participants in the assembly are defined as peers (using the name of compañero/a) no matter their role at the organization (e.g. while at the assembly, even the principal is a peer to the teaching assistants and they have equal rights for speaking and providing their point of view). From this perspective, parity (paridad) is a quality that the assembly fosters and supports. A sense of a shared common goal is what guides the exchange in the assembly, and common may mean that not everybody agrees with everything that is decided, but that if something is decided, everybody should support that decision to have it become effective.

I here highlighted the resemblance of this framework to Ferenczi's ideas on mutual associative power, authority and rights, as his 1910 piece of writing shows (as pointed out in this manuscript in the First 
Section). I also highlight the parallelism between an open space for debate, where people from diverse backgrounds but with a common purpose, may gather to think and find explanations to issues concerning them, found in Ferenczi's Budapest meetings, and what I am here portraying as CEIA's assemblies. Additionally I point out that the educators' analytical frame seems to rest in both understanding students' individual needs and contexts, and society's requirements and orientations.

2. The Womens' Reflection Group. Two psychologists and two social workers form a sub-team at the school within the bigger educators' team. This sub-team is called "Support Team" (Equipo de Apoyo). They network with other sub-teams at the school (e.g., the sub-team of physicians who visit the school once a week because they do outreach work from a public hospital nearby the school; the sub-team of teachers for each educational level within the school; the sub-team of artists who teach arts workshops, etc.).

The Support Team had documented, over time, that there seemed to be differential rights for female and male students, in detriment to the female students, and that this situation was being taken as normal by most of the students. Teachers did not find this normal, nor conducive, yet they usually had a difficult time making these issues visible to all students. Additionally, the Support Team documented several difficult situations during 2011, related to violence against female students by their male counterparts. One of the psychologists at the Support Team networked with a doctor in the team of physicians and they agreed to create a new device in 2012 ("el grupo de mujeres").

Since then, this group has met once a week and all female students who would like support in thinking through any issue they are facing, may attend. Initially the group was open to "coming and going" (entrar y salir del grupo), as students described it, but over time, it was the students who asked for continuity and for the group to be formed with regular participants (cerrar el grupo, close the group so that no more new participants could enter). In their view, it was otherwise difficult to build trust.

I have been working with the psychologist who coordinates the group since she wanted to analyze this specific device and its contribution to the students' well being. For this purpose, we have met weekly for 2 consecutive months, one hour at the time, and we have analyzed her Coordination Diary (as she calls the notebooks where she makes journal entries). We have also analyzed students' writing, and I have additionally conducted a focus group with three people who also worked with the psychologist to help coordinate the group ( 1 psychologist, 1 medical doctor and 1 nutritional specialist). In going through these sessions of analysis we identified a pattern that describes how the grupo de mujeres takes place, as follows: 
Every week the female students gather in a circle and they start by greeting each other and posing themes they would like to address that day over a two-hour meeting;

As a group they jointly decide who will start talking and about which of the several issues posed, and someone takes up the floor for presenting their story (which is the term mostly used to refer to what they share);

Other participants intervene by asking questions, providing information or adding something they think can help (e.g. a piece of information or a similar story);

Sometimes a contrasting perspective is shared as well;

Out of this shared conversation a new way of approaching what was being thought about emerges.

This pattern is similar to that documented in the weekly assemblies, as it can be noted.

The issues most frequently discussed according to the psychologists' records are health (sexual and reproductive health being the most usual), female-male relationships (including problematic issues such as physical and spoken violence or jealousy, and pleasant issues such as love, friendship and trust), and balancing your life (i.e., managing to integrate school, motherhood, relationships, and work). Since the nature of the issues more often than not need to be contextualized in participants' daily lives and -in turn- in broader situations, e.g., their relationship to their families, their responsibilities as working mothers or mothers without a job, their capacity to attend to health issues, etc., an analytic framework is constantly built into these conversations to help participants understand their range of possible actions. For example, the framework of being a working mother emerged from these meetings as one that was not very much taken into account by the students prior to entering the Womens' Group.

The coordinating psychologist has conceptualized this "grupo de mujeres" device as a "cross-roads" between a therapeutic space, an educational space, and a peer-to-peer support space. Notice, once again, the patterns that can be highlighted for this device which seem to be common to that of the assembly and of what we have discussed for Ferenczi's orientation: people from different perspectives get together, a mechanism for sharing is established by them, parity in taking up voice and in providing information or points of view is stressed, analysis of the situations is performed by participants, and an interpretation that links the issues discussed with larger societal 
issues is also brought up, often times as provided by the person who is doing the coordination, or some other times by participants themselves.

\section{Section Three. Concluding Thoughts}

In this last section I make visible the relationships between the CEIA's approach and Ferenczi's notion of mutuality taking for this purpose what I have presented in prior sections.

Firstly, I want to point out that the clinical approach, as I analyzed it here, is a perspective towards understanding reality and intervening on it. Thus it is not conceptualized as solely having a therapeutic purpose. However, healing can emerge from situations where a critical analytic framework is developed with others, in a climate of trust that includes voicing difference, in as much as the time and space of sharing with others can provide a sense of clarity by way of helping situate what is shared within larger contexts to be interpreted. In this light, mutuality helps create new conceptual insights that will in turn provide a common framework for collectively resolving something that is being posed for scrutiny.

In the CEIA, sharing with others is understood as an approach, and space and time for this specific purpose is crafted within the school's daily schedule. This possibility of sharing, geared towards analyzing and understanding, is available to the educators as well as to the students, and specific devices are implemented in order to do so. What the analysis of interactional patterns taking place both in the Weekly assemblies and the Womens' Group shows, is that the action of interpreting what participants bring to the meetings, emerge as they engage in discussion. In other words, the frameworks built to understand what is shared are not a-priori notions but are created in participants' interactions.

Secondly, the creation of understanding occurs in as much as diverse and different points of view are presented and put to work. It is by contrasting and debating with others that a sense of understanding is created. As it can be seen in both the weekly assemblies and the group of women, the fact that a perspective different than my own is presented, listened to, and worked on by all present, seems to be key. For these reasons, it is possible to support the claim that an educational experience takes place, in as much as participants transform what they know as they interact with others, or, in other words, learn.

Thirdly, it can be concluded that mutuality, a perspective we discussed in light of Ferenczi's approach to his professional work and personal position in life, is supported by a kind of relational stance that acknowledges difference, supports dialogue even if there is 
tension, and seeks to construct a community of peers with whom to think through and with whom to create new possibilities for acting differently. Ferenczi's ideas seem to be current and certainly useful if participants are willing to navigate through what it entails to jointly analyze a situation and design actions that emerge from this analysis. This is what I propose to conceptualize as a clinical-educational approach, distinctive of this particular school, and fertile to produce theoretical insights for pedagogical organizations.

\section{References}

Banki, T. (2007). Historia de Hungría desde sus orígenes hasta la actualidad. Debrecen, Hungría: Editio Mediterranica. Recuperado em https: // sede. educacion. gob.es/publiventa/ detalle. action?cod=13384

Castoriadis, C. (1992). El psicoanálisis, proyecto y elucidación. Buenos Aires, Argentina: Nueva Visión.

Dagfal, A. (2009). Entre París y Buenos Aires. La invención del psicólogo (1942-1966). Buenos Aires, Argentina: Paidós.

Ëros, F. (2010, March). Psychoanalysis behind iron curtains. Paper presented at the Symposium of Psychoanalysis and politics: Exclusion and the politics of representation. Copenhagen, Denmark.

Erös, F. (2015). Violence, Trauma and Hypocrisy. Paper presented at the International conference Psycho-Politics: The Cross-Sections of Science and Ideology in the History of Psy-Sciences, Budapest, Hungary.

Evans, R. J. W. (2006). Austria, Hungary and the Habsburgs. Central Europe c. 1683-1867. Oxford, United Kingdom: University Press.

Ferenczi, S. (1993). My friendship with Miksa Schachter. (Trans. Borisz Szegal). British Journal of Psychotherapy, 9(4), 430-433. (Original in Hungarian published 1917).

Ferenczi, S. (1997). Diario Clínico. Sin simpatía no hay curación. (Trad. José Luis Etcheverry). Madrid, España: Amorrortu. (Original en alemán 1932).

Ferenczi, S. (2009). Sobre la organización del movimiento psicoanalítico (Trad. Ricardo Wagner). In S. Ferenczi, Sándor Ferenczi. Problemas y métodos del psicoanálisis ( $p p$. 318-327). Buenos Aires, Argentina: Ediciones Hormé. (Original en alemán 1910).

Flaskay, G. (2012). From patient to founder of a psychoanalytical school. Ferenczi's influence on the work of Mélanie Klein. In J. Szekacs-Weisz \& T. Keve (Eds.), Ferenczi for our time. Theory and Practice (pp. 3-18). London, United Kingdom: Karnak Books. 
Fortune, C. (1993). Sandor Ferenczi's Analysis of 'R.N.': A critically important case in the history of psychoanalysis. British Journal of Psychotherapy, 9(4), 436-443.

Fortune, C. (1996). Mutual Analysis: A Logical Outcome of Sándor Ferenczi's Experiments in Psychoanalysis. In P. Rudnytsky, A. Bókay, \& P. Giampieri-Deustch Ferenczi's Turn in Psychoanalysis (pp. 170-186). New York, N.Y.: New York University Press.

Fortune, C. (2008). Notes and fragments of a psychoanalytic vocation, Interview on Franco Borgogno by Christopher Fortune. The American Journal of Psychoanalysis, 68, 69-95.

Fortune, C. (2015). Georg Groddeck's Influence on Sándor Ferenczi. In A. Harris and S. Kuchuck (Editors), The Legacy of Sándor Ferenczi. From Ghost to Ancestor (pp. 96-110). New York, N.Y.: Routledge.

Freud, S. (1972). Múltiple interés del psicoanálisis. In S. Freud, Obras Completas (pp. 1851-1867). (Trad. Luis López Ballesteros). Madrid, España: Editorial Biblioteca Nueva. (Original en alemán 1913)

Freud, S. \& Ferenczi, S. (2001) Correspondencia completa 19081919. Madrid, España: Síntesis Editorial.

Gutiérrez-Peláez, M. (2013). Sándor Ferenczi y la Intelectualidad Húngara del siglo XX. Affectio Societatis, 10(18), 1-12.

Hobsbawm, E. (1995). Historia del siglo XX. Barcelona, España: Crítica Grijalbo.

Haynal. A. (2001) Introducción. Los corresponsales. In E. Bravant \& E. Falzeder (Eds.), Correspondencia Completa Freud Ferenczi, 1908-1911 (pp. 27-37). Madrid: Síntesis.

Haynal, A. (2002) Disappearing and Reviving. Sándor Ferenczi in the History of Psychoanalysis. London, United Kingdom: H. Karnac Books Ltd.

Haynal, A. (2009). Die ungarische psychoanalyse unter totalitären regimen. Forum Der Psychoanalyse, 25(1), 75-89.

Heras Monner Sans, A.I., Burin, D., Di Leo, T., Durañona, C., Jaureguiberry, M., Miano, M.A., Pacheco, M. y Rocco, M. (2013). La autonomía como proyecto. Procesos de reflexión deliberada en experiencias de auto-gestión. De Pueblos y Fronteras, 8, 56-91.

Heras Monner Sans, A. I. (1993). The construction of understanding in a sixth grade bilingual classroom. Linguistics and Education, 5(3\&4), 275-279.

Heras, A. I. (1999). Taking Action with Family and Community Members: Critical Pedagogy as a Framework for Educational Change. In Zulmara Cline \& Juan Necochea (Eds.), Advances in Confluent Education (pp. 73-107). Connecticut: U.S.A.: JAl Press Inc. Stamford. 
Heras Monner Sans, A. I. (2011). Dispositivos de aprendizaje en autogestión: sus relaciones con el proyecto de autonomía. Intersecciones en Comunicación, 5, 31-64.

Heras Monner Sans, A. I. (2014a). Emancipatory Educational Processes. Anthropology News, 55(3), 1-3.

Heras Monner Sans, A. I. (2014b). Educarse en la cultura de la autogestión. Aportes sobre el aprendizaje colectivo. In Javier Encina \& Ma. Ángeles Ávila, Auto-gestión de la vida cotidiana: autonomía y auto-gestión. Sevilla, España: Creative Commons.

Heras Monner Sans, A. I. (2014c). Lógica colaborativa y generación de conocimiento colectivo. Alcances y tensiones en la relaciones investigación-sociedad. Población \& Sociedad, 21(2),137-150.

Heras Monner Sans, A. I. (2015a, agosto). Sándor Ferenczi, pensador incómodo. Aportes al pensamiento contemporáneo sobre el poder en mutualidad. I Congreso Latinoamericano de Teoría Social ¿Por qué la teoría social? Las posibilidades críticas de los abordajes clásicos, contemporáneos y emergentes. Buenos Aires, Argentina.

Heras Monner Sans, A. I. (2015b). Práctica cotidiana escolar, reflexión docente y posicionamiento en política pública. Análisis de intercambios en asambleas semanales. Archivos Analíticos de Políticas Educativas, 23(98), 1-40.

Heras Monner Sans, A. I. (2015c). Análisis del aprendizaje sobre la auto-gestión. La cuestión específica de los aportes y distribución de recursos. Cuadernos Antropología Social (40), 129-148.

Katz, C. S. (1977). Psicanálise e instituiçaoo. Rio de Janeiro, Brasil: Editora Documentário.

Likierman, M. (1993). 'He drew my attention to my great gift for understanding children ...' some thoughts on Sandor Ferenczi and his influence on Mèlanie Klein. British Journal of Psychotherapy, 9(4), 444-455.

Mészáros, J. (1998) The Tragic Success of European Psychoanalysis: The Budapest School, International Forum of Psychoanalysis, 7(4), 207214.

Mészáros, J. (2009). Sándor Ferenczi and the Budapest School of Psychoanalysis. Paper read on the opening ceremony of the Ferenczi Center at the New School for Social Research, New York, N.Y.

Montejo-Alonso, F. J. y Chamorro-Romero, E. (2011). El psicoanálisis 1919-1933: consolidación, expansión, institucionalización. Madrid, España: Universidad Complutense de Madrid.

Moreau-Ricaud, M. (2004). La question de la formation analytique: Trois apports essentiels de l'école de Budapest. Le Coq-Héron, 178(3), 112-121. 
Peres, S. P. (2015). A fenomenologia de Husserl no contexto da psicologia na virada para o século XX. Estudos e Pesquisas em Psicologia, 15(3), 986-1005.

Stanton, M. (1993). Introduction. British Journal of Psychotherapy, 9(4), 428-429.

Roudinesco, E. (2015). Freud en su tiempo y en el nuestro. Buenos Aires, Argentina: Penguin Random Group Editorial.

Tilly, C. (2010). Los movimientos sociales: 1768-2008. Barcelona, España: Crítica.

Tubert-Oklander, J. (2013). Theory of Psychoanalytical Practice: A Relational Process Approach. London, United Kingdom: IPA Psychoanalytic Ideas and Applications Series: Karnak Books.

Wallerstein, I. (2011). The Modern World-System IV. Centrist Liberalism Triumphant, 1789-1914. Los Angeles, CA: USA: University of California Press.

\section{Endereço para correspondência}

Ana I nés Heras Monner Sans

Centro de Estudio de las Desigualdades, Sujetos e Instituciones, CEDESI-UNSAMCONICET

Martín de Irigoyen, 3100, 1650, San Martín, Buenos Aires, Argentina

Endereço eletrônico: aheras@unsam.edu.ar

Recebido em: 03/02/2016

Aceito em: 04/04/2017

\section{Notas}

* National Researcher from the National Research Council in Argentina at the CEDESI in the School of Humanities (UNSAM) and at the Social Inclusion and Development Institute. She specializes in ethnography and sociolinguistics applied to the study of self-managed group practices and processes.

Este artigo de revista Estudos e Pesquisas em Psicologia é licenciado sob uma Licença Creative Commons Atribuição-Não Comercial 3.0 Não Adaptada. 